\title{
STUDI OPTIMASI KROMIUM (VI) DALAM AIR LAUT SECARA VOLTAMMETRI STRIPPING ADSORPTIF
}

\author{
Deswati, Hamzar Suryani, Imelda dan Yulia \\ Kimia Universitas Andalas
}

\begin{abstract}
Study of optimation chromium (VI) in sea water by adsorptive stripping voltammetry has been done. The aim of this method to get optimum conditions for determination of $\mathrm{Cr}(\mathrm{VI})$. Adsorptive stripping voltammetry (AdSV) has been used for the ultra trace determination of chromium using 2,2'- bipyridin as ligand. Parameters were done, like accumulation time, concentration of ligand, $\mathrm{pH}$, accumulation potential, electrolyte concentration and catalyst concentration. In this case, the optimum conditions were reached in accumulation time 80 second, $\mathrm{pH} 5.0$, concentration of 2,2'bipyridin $10 \mu \mathrm{M}$, accumulation potential $-0,6$ Volt and electrolyte concentration $\left(\mathrm{NH}_{4} \mathrm{Cl}\right) 0,1 \mathrm{M}$. In the optimum conditions, a linear calibration graph was obtained with correlation coefficient of 0.9971 , the relative standard deviation was $15.06 \%$ for eight replicates $(n=8)$ measurements of 10 $\mu \mathrm{g} / \mathrm{L}$ of $\mathrm{Cr}(\mathrm{VI})$. The detection limit method was $0.1692 \mu \mathrm{g} / \mathrm{L}$. The method was applied to the direct determination of $\mathrm{Cr}(\mathrm{VI})$ in sea water around Muara Padang water. Concentration $\mathrm{Cr}(\mathrm{VI})$ in sample was equal to $0.9684 \mu \mathrm{g} / \mathrm{L}$ with recovery of $90.23 \%$.
\end{abstract}

Keywords : optimation, chromium, adsorptive, stripping, voltammetry

\section{DAFTAR PUSTAKA}

1. R. Jugade dan A. P. Joshi, Highly Sensitive Adsorptive Stripping Voltammetric Method For The Ultra Trace Determination Of Chromium(VI), Anal Sci., 22: 571 - 574, (2006).

2. G. Svehla dan Vogel, Buku Teks Analisis Anorganik Kualitatif Makro dan Semimikro, edisi ke-5, terjemahan L. Setiono dan A. H. Pudjaatmaka, PT. Kalman Media Pusaka, Jakarta, $1989,270-275$.

3. Menteri Negara Kependudukan dan Lingkungan Hidup, Keputusan Mentri Negara Kependudukan dan Lingkungan Hidup Nomor 02/MENKLH/1988 tentang Baku Mutu Air Laut Untuk Biota Laut. Sekretariat MENKLH, Jakarta, 1988.

4. S. M. Khopkar, Konsep Dasar Kimia Analitik, UI-Press, Jakarta, 1990, 351 354 dan $366-368$.

5. H. A. Strobel dan W. R. Heinemann, Chemical Instrumentation, a Systematic Approach, $3^{\text {rd }}$ ed., John Willey and Sons, New York, 1989, 1071 dan $1134-1139$.
6. M. K. Amini and M. Kabiri, Determination of Trace Amounts of Nickel By Differential Pulse Adsorptive Cathodic Stripping Voltmmetry Using Calconcarboxylic Acid as a Chelating Agent, Journal of the Iranian Chemical Society, 2: 32 - 39, (2005).

7. M. Korolezuk, et. al, Adsorptive Stripping Voltammetry of Nickel and Cobalt at in situ Plated Lead Film Electrode, Electrochem. Commun., 7: 1185 - 1189, (2005).

8. A. Triadi, Pengaruh dan Konsentrasi Pengompleks dalam Penentuan Nikel (II) secara Voltammetri Stripping Adsorptive, Skripsi Sarjana Kimia Universitas Andalas, Padang, 2008.

9. A. Babaei, et. al, Simultaneous Determination of Copper, Bismuth and Lead by Adsorptive Stripping Voltammetry in the Presence of Thymolphthalexone, Anal. Sci., 22: 955 - 959, (2006).

10. J. C. Miller, J. N. Miller, Statistik untuk Kimia Analitik, edisi ke-2, Penerbit ITB, Bandung, 1991, 52-66. 
11. Anonim., Voltammetry, an Introduction in Theory, Methrom Ltd., CH-9100 Herisau Switzerland. 